\title{
Interfaith Dialogue in an African Context
}

\author{
Falres Ipyana Ilomo \\ Faculty of Theology- University of Iringa-Tanzania
}

\begin{abstract}
This paper is going to discuss about the process of interfaith dialogue in an African perspective. The type of interfaith dialogue shall be different from the traditional Western perspective. In a traditional form, normally dialogue involves the so called world major religions namely, Christianity and Islam only. Both of these two religions are foreign religions originated from the Middle East. In African perspective the two religions are foreign, therefore, according to science of religions, they are known as secondary religious experience. However, the African religion to Africans is primary religious experience at the same time this religion is the host to the two religions (Islam and Christianity). This study shall propose the dialogue to be carried out in a modern way, unlike the traditional one. In this new type of dialogue, African religion shall be treated equally with other foreign religions. The objective of this dialogue is to learn to tolerate as well as enriching from each other. The study shows that from the end of the 19th and beginning of 20th century, the Roman Catholic Church did not recognize whether Africans had a religion at all. However, from 1969 up to 1993, the Roman Catholic Church started to recognize the African religion. A contribution to interfaith dialogue by Western, Asian and African scholars in Religions shall give a great contribution to the study of interfaith dialogue in a new perspective.

Keywords: dialogue of living together, convivenz, second Vatican Council, primary and secondary religious experiences
\end{abstract}

DOI: $10.7176 / \mathrm{JPCR} / 52-03$

Publication date: February $28^{\text {th }} 2021$

\section{Dialogue-Introduction}

Dialogue is a frank discussion between two parties, aimed at reaching a better understanding of each other's point of view. Moreover, the parties work out on a compromise that has been acceptable to both sides. Normally, it is a human habit to have an attitude of respect and friendship towards those who have a different point of view or faith from one's own. During such a genuine dialogue, it is expected that there must be flexibility and openness to truth no matter from which side it comes. So that the search for truth may be free, the participant in dialogue seeks to eliminate every prejudice, intolerance and unnecessary misunderstanding. Dialogue shows openness to the activity of the spirit in each person and each religion or group, and hence a readiness to accept the depth of the religious experience of others and to co-corporate with them for the good of the religion and community. ${ }^{1}$

Thus, a working definition of dialogue could be given as a frank exchange of viewpoints between two or more persons with the scope of enriching each other, leading to increase in the knowledge about each other's beliefs and convictions, and the removal of ignorance and or prejudice about the same. Moreover, we can give the ultimate aim and purpose of interreligious dialogue as to bring all believers to the realization that we are all children of the same Father God. ${ }^{2}$

After looking into the general information about dialogue, in the following sections, the study will be focused on the dialogue in the African context. Hence, the study will deal with the attitude of the church towards African religion; various models of interreligious dialogue; what can the church experience from African religion and what can African religion adherents experience from Christianity respectfully.

\subsection{Inter-Religious Dialogue with African Religion}

For the whole time since Christianity was introduced in Africa, there has been no dialogue with African religion; instead mission was done in a form of proselytization whereby, Christianity has been so violent to African religion and culture. On the other side, always there has been dialogue between Christianity and Islam, Judaism, Buddhism, Hinduism etc. In most African communities: some places there are Muslims while in others there are no Muslims at all. In some places there are African religion followers only, or African followers living together with Christians. But to our surprise the church in Africa is conducting dialogue with Islam only as if in all communities there are only Muslims living with Christians. In other words we can conclude that the presence of African religion followers is not recognized by the church besides the fact that Christianity was introduced since 1500s. This attitude of not recognizing the presence of African religion followers, in one hand can have been influenced by the church traditions from the time she started to do world mission as can be seen in the following section bellow.

\footnotetext{
${ }^{1}$ www.afrikaworld.net/afrel/metuh.htm

${ }^{2}$ Ibid. www.africaworld.net/afrel.metuh.htm
} 


\section{Church Attitude towards African Religion}

In this section we will evaluate the church attitude towards African religion in the end of the $19^{\text {th }}$ century and mid of $20^{\text {th }}$ century. The Roman Catholic Church attitude shall be taken as an example to represent other Protestant Churches as reported by Chidi Denis Isizoh. He gives an account of the negative picture painted of a non-Christian religion in Church documents and expressions of the pre-Vatican II Council. He underlines some of the official position of the Catholic Church (in relation to documents that guided missionary implantation of the Gospel in Africa) towards other religions expressed in three different documents in:

1. Letter of Pope Leo XII (Catholicae Ecclesiae) of 1890; 2. The Apostolic Letter of Pope Benedict XV (Maximum Illund) of 1919; 3. And the Encyclical Letter of Pope Pius XI (Rerum Ecclesiae) of 1926. Apart from the fact that these documents came from the highest authority of the Church on earth, they indicated the theological/pastoral direction that all Christians, especially the missionaries were meant to follow. ${ }^{1}$

Pope Leo XIII, while urging the missionaries to go beyond protecting slaves to stopping the evil practice of the slave trade, expressed his "apostolic concern" for the missionary activities in Africa. When writing about Africans in Catholicae Ecclesiae, he instructed the missionaries to "bathe those inhabitants living in darkness and blind superstition with the light of divine truth, by which they can become co-heirs with us of the Kingdom of God." 2

In Maximum Illund, Pope Benedict XV referred to the followers of non-Christian religions as "the numberless heathen who are still sitting in the shadows of death. According to recent statistics, their number accounts to thousand million..." These peoples stood in the need of the "benefits of divine redemption." It was the task of Bishops "to light the torch for those sitting in the shadows of death, and open the gate of heaven to those who rush to their destruction." Religious superiors and heads of congregations engaged in missionary work were requested after having "successfully accomplished their task and converted some nations from unhallowed superstition to Christian faith and have founded there a church with sufficient prospects, they should transfer them, as Christ forlorn hope, to some other nations to snatch it from Satan's grasp."”

In Rerum Ecclesiae, Pope Pius XI considered it a great act of charity on the part of missionaries to withdraw "pagans...from the darkness of superstition" in order to instruct them "in the true faith of Christ." Thus each missionary, as ambassador of Christ, must "bravely face all hardships and difficulties, as long as he can snatch a soul from the mouth of hell". ${ }^{4}$

The same Pontiff encouraged vocation to the Priesthood especially for "the heathens particularly those who are still savages and barbarians". He urged European missionaries to have patience, saying: "if you find extreme slowness of mind in the case of men who live in the very heart of barbarous regions, this is due to the conditions of their lives, for, since the exigencies of their lives are limited, they are not compelled to make great use of their intelligence."

The desire to save the people from the "darkness of superstition," went beyond mere instruction of them "in the true faith of Christ" to an overall cultural advancement and civilization of "uncivilized peoples". Hence the European system of education was introduced and promoted by missionaries who also preached a theology of discontinuity - which urged Africans of the time to break with African religion in order to embrace Christianity. ${ }^{6}$

As an application to what the Pope commanded, the missionaries implemented in various ways as seen bellow:

In Gabon, for example, the earliest missionaries to the country equated the traditional religion with fetishism and idol worship. The goal of the missionary action was to wipe out this paganism which was also considered barbaric by the colonizers. The result of it was the disappearance of the African traditional religion as a religious institution. What remain today are only aspects of initiation, healing, and clairvoyance. ${ }^{7}$

Among the Igbo and Efik/Ibibio peoples of Nigeria, the early missionaries inserted in the "missionary" catechism of the Christian faith a list of mortal sins, the first, literally translated, reads: "joining the pagans in idol worship, invoking the spirits, sacrifice, keeping of amulets and believing in them as God, making deadly charms, celebrating funeral rites in a pagan way, or participating in such rites". All these terms reveal the interpretation given to the religious expressions of the followers of African religion who were, in any case, regarded as pagans. In some of African countries prayers were composed for the conversion of African peoples "wandering in the veil of darkness where they are destined to be lost forever...." unless they turned to Christianity. Converts from African religion to Christianity were frightened into abandoning almost everything

\footnotetext{
${ }^{1}$ Chidi Denis Isizoh, Dialogue with African Traditional Religion in Sub-Saharan Africa: The Changing Attitude of the Catholic Church, p. 4

${ }^{2}$ Ibid. Isizoh, p. 4

${ }^{3}$ Ibid. Isizoh, pp. 4-5

${ }^{4}$ Ibid. Isizoh, p. 5

${ }^{5}$ Ibid. Isizoh, p. 5

${ }^{6}$ Ibid. Isizoh, p. 5

${ }^{7}$ Ibid. Isizoh, pp. 5-6
} 
the traditional religion and culture had to offer. ${ }^{1}$

\subsection{The Second Vatican Council}

The Second Vatican Council made a major breakthrough in the relationship between the Catholic Church and other Religions when the council directed all Christians to develop a positive attitude towards other believers. Furthermore, the council opened a door for positive discussions about other religions. In one of its earliest documents, Lumen Gentium, it affirmed that salvation is possible for other believers outside the visible Christian fold:

The plan of salvation includes those also who acknowledge the Creator... with us, adore the one and merciful God who will judge mankind on the last day. Nor is God far from those who in shadows and images seek the unknown God; for He gives to all men life and breath and all things, and as Saviour desires all men to be saved. For those also can attain eternal salvation who without fault on their part do not know the Gospel of Christ and His Church, but seek God with a sincere heart, and under the influence of grace endeavour to do His will as recognized through the promptings of their conscience. ${ }^{2}$

In Gaudium et Spes the Council encouraged dialogue among all men. This dialogue springs from mutual respect and love which should be found in all spheres of human interaction:

Respect and love ought to be extended also to those who think and act differently from us in social, political and even religious matters. In fact, the more deeply we come to understand their ways of thinking through sympathy and love, the more easily shall we be able to enter into dialogue with them. We ... turn our thoughts to all those who acknowledge God and preserve in their traditions precious elements of religion and humanity. We wish that a frank dialogue may lead us all to welcome faithfully the impulses of the Spirit and to carry them out courageously. ${ }^{3}$

The Council then urged all Christians "to enter with prudence and charity into discussion and collaboration with members of other religions. (And)... while witnessing to their own faith and way of life, (they should) acknowledge, preserve and encourage the spiritual and moral truths found among non-Christians, also their social life and culture." 4

Besides the positive attitude to other religions, the specific reference was made in Nostra Aetate to relations with Muslims and Jews only. But African traditional religion was not mentioned by name. It took another three years (1969) before the great Pope Paul VI, the first to set foot on the soil of Africa sub-Sahara, spoke gloriously about Africa, its rich traditions, culture and religion. ${ }^{5}$

\subsection{Pope John Paul IV}

Already in his first encyclical letter, Ecclesiam Suam, the Pope mentioned by name "followers of the great religions of Africa and Asia". In Africae terrarium, he pointed out the various precious elements found in the African worldview which the Church appreciates and respects:

We think it profitable to dwell on some general ideas which typify ancient African religious cultures, because we think their moral and religious values deserving of attentive consideration. The constant and general foundation of African tradition is the spiritual view of life. Here we have more than the socalled "animistic" concept, in the sense given to this term in the history of religions at the end of last century. We have a deeper, broader and more universal concept which considers all living beings and visible nature itself as linked with the world of the invisible and the spirit. In particular it has never considered man as mere matter limited to earthly life, but recognizes in him the presence and power of another spiritual element, in virtue of which human life is always related to the after-life. In this spiritual concept, the most important element generally found is the idea of God, as the first or ultimate cause of all things.

This concept, perceived rather than analyzed, lived rather than reflected on, is expressed in very different ways from culture to culture, but the fact remains that the presence of God permeates African life, as the presence of a higher being, personal and mysterious. People have recourse to Him at solemn and more critical moments of life, when they consider the intercession of every other intermediary unavailing. Nearly always fear of God's omnipotence is set aside and He is invoked as Father. Prayers made to Him, whether by individuals or by groups, are spontaneous, at times moving, while among the forms of sacrifice of first fruits stands out because of what it plainly signifies..... For Africans the family thus comes to be the natural environment in which man is born and acts, in which he finds the necessary protection and security, and eventually through union with his ancestors has his continuity

\footnotetext{
${ }^{1}$ Ibid. Isizoh, p. 6

2 Ibid. Isizoh, pp. 6-7

${ }^{3}$ Ibid. Isizoh, p. 7

${ }^{4}$ Ibid. Isizoh, p. 8

${ }^{5}$ Ibid. Isizoh
} 
beyond earthly life.

.... As regards community life -which in African tradition, was family life... We note that participation in the life of the community, whether in the circle of one's kinsfolk or in public life, is considered a precise duty and the right of all. But exercise of this right is conceded only after progressive preparation through a series of initiations whose aim is to form the character of the young candidates and to instruct them in the traditions, rules and customs of society. ${ }^{1}$

As one of the early signs of the opening of the Catholic Church to other non-Christian religions encouraged by the second Vatican Council, Pope Paul VI established the Pontifical Council for Interreligious Dialogue and charged it with the specific assignment to "become a means by which to arrive at a sincere and respectful dialogue with those who 'still believe' in God and worship Him."

Throughout the papacy of Paul VI African tradition religion and culture received a very good mention at the central offices of the Catholic Church. The Congregation for Institutes of Consecrated life and for Societies of Apostolic life, for example, addressed a Message to Religious Men and Women of Africa in October 1976 in which a call was made to Africans to "Africanize religious life" and "integrate into it the values of the African culture in harmony with the Gospel". Some documents published, and initiatives promoted, by the Pontifical Council for Interreligious dialogue portrayed African Traditional Religion and Culture in good light. ${ }^{3}$

\subsection{Pope John Paul II}

The direct contact with followers of African traditional religion had to wait till the papacy of John Paul II who has shown clearly not only his appreciation of traditions and cultures but also interest in and respect for the religion which has given coherence to the African person. Like his predecessor (Paul VI), Pope John Paul II praised the many positive values found in African traditions and cultures that can help the African person to be open to the Gospel of Jesus Christ. He encouraged Africanisation, indigenisation, inculturation, etc. of these values. Addressing the Bishops of Kenya, on ad Limina visit, he asserts:

I am close to you, in praise and encouragement, in every undertaking of yours to communicate Christ, to make his Gospel incarnate in the lives and culture of your people... The "acculturation" or "enculturation" which you rightly promote will truly be a reflection of the Incarnation of the Word, when a culture, transformed and regenerated by the Gospel, brings forth from its own living tradition original expressions of Christian life, celebration and thought. By respecting, preserving and fostering the particular values and riches of your people's cultural heritage, you will be in a position to lead them to a better understanding of the mystery of Christ, which is to be lived in the noble, concrete and daily experiences of African life. There is no question of adulterating the word of God, or of emptying the Cross of its power, but rather of bringing Christ into the very center of African life and of lifting up all African life to Christ. Thus not only is Christianity relevant to Africa, but Christ, in the members of his Body, is himself African. ${ }^{4}$

The same Pope John Paul II introduced a new dimension to the dialogue with the followers of African traditional religion. On 4 February 1993 he met and addressed the followers of African traditional religion in Benin Republic. Inter alia, in his address the Pontiff told them:

I am happy to have this opportunity to meet you, and I greet you most cordially.... You have a strong attachment to the traditions handed on by your ancestors. It is legitimate to be grateful to your forebears who passed on this sense of the sacred, belief in a single God who is good, a sense of celebration, esteem for the moral life and for harmony in society. ${ }^{5}$

By addressing the followers of this religion, he was sending a message to the whole world. African traditional religion is not an archaic religion of primitive people fit only for study by ethnologists, sociologists and students of religion. It is not a religion for the museum. In the eyes of the Pope, it is a religion of a living people. And being part of the yearning of humanity for God, the religion deserves respect and should be considered alongside other non-Christian religions. The Pope himself gave the following advice:

The adherents of African traditional religion should... be treated with great respect and esteem, and all inaccurate and disrespectful language should be avoided. For this purpose, suitable courses in African traditional religion should be given in houses of formation of priests and religions. ${ }^{6}$

If we follow from the beginning the sections above, we can see first, how the Roman Catholic Church did not officially recognize African belief as one of world religions, especially in the years 1890, 1919 and 1926.

\footnotetext{
Ibid. Isizoh, pp. 9-10

${ }^{2}$ Ibid. Isizoh, p. 10

${ }^{3}$ Ibid. Isizoh, pp. 10-11

${ }^{4}$ Ibid. Isizoh, pp.11-12

${ }^{5}$ Ibid. Isizoh, pp. 12

${ }^{6}$ Ibid. Isizoh, pp. 12-13
} 
However, from 1969 we see the Pope's attitude towards African religion has changes tremendously. In one way we can praise the Roman Catholic Church for making a great turning point towards African tradition religion. On the other side we can ask ourselves whether this change can benefit the church for the time being.

Besides the fact that the command for change is from the top most authority, however, there are doubts whether this attitude can affect clergy who might have been influenced by the Western concept of denial of African Religion due to the teaching they have been receiving in the theological training institutions. Moreover, the changes cannot necessarily affect the lay Christians since for them what they received from the former missionaries cannot be changed. On my side I think the changes can benefit the coming generation rather that our generation. It has taken too longer to bring changes to the church in regard to African religion. Therefore, denial of African religion for all these years has caused a lot of damage. However, besides, the Roman Catholic to take steps too late, on one side we can praise her, when we compare with Protestant Churches, who have not even started recognizing African religion.

\section{Models of Dialogue}

\subsection{Intra-Religious Dialogue by Panikkar}

According to Raimon Panikkar, the inter-religious dialogue is generally carried out by expert or representatives of different belief-system or artistic sensitivities. When the dialogue catches hold our entire person and removes our many masks, because something stirs within participants, then participants begin the intra-religious dialogue. This is the internal dialogue. In this dialogue, something stirs in the inmost recesses of participants being that they do not often dare to verbalize too loudly. That moment can lead to a purifying individual solitude or to destructive individualistic isolation. ${ }^{1}$

In brief, the intra-religious dialogue is itself a religious act, an act that neither unifies nor stifles, but re-links participants (in all directions). It takes place in the core of our being in our guest for salvific truth. We engage in such a dialogue not only looking above, towards a transcendent reality, or behind, towards and original tradition, but also horizontally, towards the world of other people who may believe they have found other paths leading to the realization of human destiny. The search becomes an authentic prayer open in all directions. ${ }^{2}$

The first steps of the intra-religious dialogue take place in the depths of the person. This dialogue is open to the religiousness of our neighbours. How else could we love them as ourselves? Their beliefs become a personal religious question. It is also profound. It is no longer concerned with mere formulations (of our own traditions or other people). It is a personal question concerning the meaning of reality-salvific truth. The intra-religious dialogue is an internal dialogue in which one struggles with oneself. How can we have access to the whole of a liberating truth if our neighbours seem to have other beliefs, which are sometimes totally incompatible with our own convictions? In this dialogue, we are in search of salvation, and we accept being taught by others, not only by our own clan. ${ }^{3}$

\subsubsection{Challenge to Panikkar's View}

From Panikkar's view on inter-religious dialogue, it seems clearly that he is dealing with institutionalized religions like Christianity, Islam, Hinduism, Buddhism, Judaism etc. In the context of Panikkar, the members of the neighbor religion is not part of the blood relation. Therefore, no sharing of culture and language of which the one who wishes to participate the interreligious dialogue must be willing to learn from the other part. Therefore, the aim of this inter-religious dialogue is to help a member to understand the religion of the other part. This is in fact a preparation for intra-religious dialogue that has to take place internally among members of the same part.

The model for Panikkar's case in regard to interfaith dialogue, is primarily not for missionary purpose but is for the sake of living together harmoniously with the followers of other religion. Moreover, Panikkar proposes the participants of inter-religious dialogue to be among the scholars of that particular religion. However, It is not clearly stated how this model of upper class of scholars are going to spread the knowledge to the grass root. However, Panikkar's model of intra-religious dialogue which is preceded by interfaith dialogue, is aimed to enrich the participants of dialogue of one part. However, Panikkar does not explain how other people from the grass root in that particular religion are going to benefit in the intra-religious dialogue that occurs inside the minds of participants (representatives of that religion). We can therefore easily conclude that, intra-religious dialogue is for the sake of representatives of religious groups rather than ordinary people as shall be the case in the African context.

\subsection{Dialogue with Traditional Religions? By Theo Sundermeier}

According to Sundermeier's research, interreligious dialogue is conducted today at three levels: 1 . At conferences of representatives of various religions; 2. In local congregations; and 3. Occasionally in university

\footnotetext{
${ }^{1}$ Panikkar, Raimon. (1999- p.xvi). Intra- Religious Dialogue, revised ed. Paulist Press New York-Usa,

${ }^{2}$ Panikkar, Raimon. p. xvii

${ }^{3}$ Ibid. Panikkar
} 
theology faculties. At the first level, there are no representatives of African religion. The immediate reason is that it cannot be represented by any umbrella institution or association, and the individual African religion has hardly any spokespersons. The office of priest, where it exists at all as a separate calling (mainly in West Africa), rarely involves teaching. Moreover, the teacher-elders among the Chagga are atypical, and are more concerned with passing on traditions than with specifically religious instruction. ${ }^{1}$

At the level of African congregation, a relationship of dialogue is developing only very slowly, with representatives of African religion, because they feel forced on to the defensive by aggressive mission, and are made to feel that their culture is inferior. On the other hand, church communities regard African religion as a hidden threat, because it is known to have the power of infiltrating a congregation and assimilating parts of it. Only within the framework of a growing national consciousness, in which Africans are seeking to understand their own roots and cultural traditions, are theologians beginning to study African religion. Concerned for the indigenization of worship and theology, these are the people who speak up for traditional religion at the dialogues organized by ecumenical organizations such as the World Council of Churches. ${ }^{2}$

At the level of interreligious theological dialogue at universities, African religion is in fact hardly ever mentioned, except in academic articles or at the occasional conference. The reason is that African religion has no elaborate doctrines, and is unfolded in ritual rather than in discourse. Recent research has only just begun to reveal the riches of primal religious conceptualization-but this is not sufficient explanation for the neglect. The more fundamental reason lies in the deep-rooted prejudice that traditional religious differ essentially from the "higher religions," according to the German Philosopher Hegel (1770-1831) they are not worthy of the name of religion, because people (he meant the Europeans of that time) would have to forget virtually all the concepts and ideas they had learned if they wanted to explore and understand these religions. To this day, the prevailing view of indigenous cultures, whether expressed openly or not, is that they are "magical" rather than religions in the Western sense of the world. This must be the entry point for academic dialogue with traditional religions. Only when relations between traditional and world religions are freed from the encrustations and prejudice of the past, and placed on a new footing, can real dialogue begin. This should, however, be a dialogue in community, arising out of "conviviality" (German Konvivenz), in the deeper sense of living together. And it should take place in Africa, not in Europe. ${ }^{3}$

\subsubsection{Conclusion on Sundermeier's Model}

Regarding Sundermeier's observation, it is true that in the model of interreligious today as it was in the past, there is no representation from African religion because of not recognizing it as a religion. Therefore, Sundermeier suggests the role of today's African scholars as to remove the historical prejudice. He also remarks that interreligious dialogue at the congregational level is very slowly and is done for the sake of aggressive mission. However, I think if there is at all interreligious dialogue at congregational level, must have taken in the context where Sundermeier was working as a missionary in Namibia as well as in Natal- South Africa. Otherwise, this dialogue is not common elsewhere in African Churches.

Sundermeier is also pointing out that, due to the fact that national consciousness is now growing and eventually led the African scholars to seek to understand their own roots and cultural traditions by studying African religion. However, from practical experience it seems that the scholars are doing this task as their own hobby because such researches have no connection with the church life and since African scholars are not teachers of the church but only teachers of university students, the researches done by scholars, do not benefit the church at all. In connection to this, even the efforts done at the highest ecumenical level of the Church (World Council of Churches) where they discuss about indigenization of worship and theology, the outcome does not reach the grass root level in the individual churches in African countries. Nevertheless, the type of dialogue proposed by Sundermeier, "dialogue in the community," or dialogue arising out of "conviviality" (living together) seems to be practical for the African context today due to the fact that it is part of African world view of hospitality and community life.

\section{Inter-Religious Dialogue from the African Context}

Interreligious dialogue in the African context today is crucial and must be presided by intra-religious dialogue. When we speak of intra-religious dialogue (or internal dialogue in which one struggles with oneself) in an African context, we are aware that African religion is not operating as an institution. In African context, religion is also not confessed but lived. In this religion, there is also no written scriptures to be followed, but the belief is practiced in daily life. Since African religion is not institutionalized, inter-religious dialogue shall be done by considering the Africans as community members at large. This inter-religious dialogue in Africa must be preceded by intra-religious dialogue or dialogue ad intra, to borrow the terminology from Chidi Isizoh, can be

\footnotetext{
${ }^{1}$ Sundermeier, Theo. (1998-p.233). The Individual and Community in African Traditional Religions. LIT VERLAG, Hamburg.

${ }^{2}$ Ibid. Sundermeier

${ }^{3}$ Ibid. Sundermeier, pp. 233-234
} 
done as a preparation for inter-religious dialogue. Isizoh underlines that dialogue ad intra is a dialogue with Africans who are now Christians but would like to retain some or all the precious values from African religion and culture. ${ }^{1}$

In the course of intra-religious dialogue, the Christian church shall lead her members to discuss and consider the following points so as to help them change their mind set influenced my missionary teaching regarding African religion:

1. To revisit African religion from African scholarship: is African religion an idol worship; are forebears Satan?

2. Are all African cultural elements devil?

3. Do African believers of Christianity need to act like Westerners or can they remain "African Christians" after their conversion to Christianity?

4. What does incarnation mean to Africans? Can this incarnation take place in African context or is limited to Middle-East and Western World only?

Different from other partners of interreligious dialogue, when preparing for this dialogue, the church in Africa must bear in mind that the other part of dialogue partners are part of their respective community. They share language, culture, blood relationship and primary religious experience, since the Christian members were formerly members of African religion before converting to Christianity. In other words, Christian church is preparing for interreligious dialogue with people whom they already know and they are part of the blood relationship. Therefore, the dialogue can be easy or difficult in case the dialogue is not sincere and respectful.

\subsection{Convivium Model}

The word, convivial means, sociable, hospitable or conviviality or sociability is a Latin word from, convivium, which means social feasting (eating and drinking) together with friends. ${ }^{2}$ Convivium, or dialogue ad extra, ${ }^{3}$ if we use Isizoh's terminology, is the model that shall be applied in this discussion, especially when dealing with interreligious dialogue in the frame work of African context. In this model of convivium, I will deal with two goals: The first goal is dialogue that can revive the relationship among community members regardless of religious differences. The second goal of dialogue shall be for the sake of mission. In this case, the goal shall be to change the approach of doing mission from the inherited approach of proselytization to doing mission through dialogue with followers of African religion.

\subsubsection{Revive Relationships}

The interreligious dialogue in the African context shall be in the model of convivium as stated above. This model of dialogue is aimed at promoting dialogue in form of living together between Christians and followers of traditional religion, different from the missionary time where there were two interrelated communities. Since these people live in one community, belong to similar tribe or clan, speak similar language, share similar culture and tradition, and share the same human predicaments, they need to relate each other and share their joy and sorrow. The proposed model of convivium is relevant to the African context. In this model, all people from grass root to the leaders shall share dialogue equally unlike the model in the dialogue with Judaism, Islam, and Buddhism etc where only representatives of religious (normally scholars) institutions take part in dialogue.

The areas of relationship that must be revived include: Christians to participate in their respective clan's communal meals, participate in initiation ceremonies such as puberty, naming of child etc; participate in funeral ceremonies since from church tradition Christians were not allowed to take part in such ceremonies as they are regarded pagan practices. In Africa, the European missionaries established demarcation between church funeral and pagan funeral or church burial service and pagan burial service, the practice observed to this day. In general I can say that the introduction of Christianity in Africa meant also separation of family ties. A community member is separated from his/her relative due to religious belief whereby, Christians are not allowed to participate in traditional practices together with their relatives.

\subsubsection{Dialogue and Mission}

When Christianity was introduced in Africa from 1500s, missionary approach was in the form of proselytization and not in the form of dialogue. Moreover, the missionaries expected conversion to be a rapid change and not as social process. The missionaries also wanted Christianity to play a replacement role to African religion, something that was contrary to African perspective. For them, conversion was not a rapid change, but a social process. Moreover, Christianity which was to them secondary religious experience played an additive role to (African religion) their primary religious experience. Worse enough, until today, mission work in Africa is still done in the form of crusade.

In Tanzania, like other countries in Africa, mission in the form of crusade is still popular. It is sometimes

\footnotetext{
Chidi Denis Isizoh, in: Dialogue with African Traditional Religion in Sub-Saharan Africa, p. 32

${ }^{2}$ Dictionary of Etymology (1988). Barnhart, K. Robert (Ed.). The H.N. Wilson Company-USA

${ }^{3}$ Isizoh, p. 31
} 
called, "open air preaching." This preaching is done normally by lay Christians who are having very ambitious titles; one of them is called, "Mzee wa Upako," which literally means, "Holy Spirit giver preacher" or "miracle maker." Another one calls himself as "Ngurumo ya upako," which literary means, a "thunderstorm preacher." To be concrete, an example can be derived from one case where one group of this nature is doing mission in villages or small towns in Iringa region, Southern part of Tanzania. This group is registered under the name, "New Life Crusade." However, from 2008, the movement has changed her name to be, "New Life in Christ." When the group in 2005 reached a village in Makete District Council called Utengule, preached for two weeks consecutively. After finishing their task and ready to return back home (in Iringa), one man who was among the listeners in that crusade (he was a traditional priest) asked the preachers as follows:

You have been preaching for the whole time and I was only listening to you and you did not give me a chance to speak on my side. I am not against what you have been teaching. Whether there is salvation through Jesus Christ or not I have no objection. Before you leave, I request three of you to remain with me for three months. I am a clan leader, if I am converted to Christianity and my community members ask me about this new teaching, they can answer them on my behalf and at the same time I will be learning how to answer such questions during your absence.

However, one of the preachers responded to him, "we have been here for two weeks preaching to you and you didn't take the opportunity to surrender your life to Jesus Christ. We have finished our task. It is now up to you, to accept Jesus as your personal savior or face consequences at the Day of Judgment. We have left our businesses in Iringa for two weeks. It is now time for us to go back and continue with our daily routines ..."

Regarding the case above, we can conclude that the intention of preachers was genuine. They intended to preach the word of God so as to convert unbelievers and inspire the ones who were already Christians. However, we can ask ourselves whether the approach applied was it proper? If some people were converted Christians in that manner, were they strong believers or just believers without having roots.

Regarding the traditional priest who complained that the preachers worked for the whole time without asking from his side, in one way he was right. How can a traditional priest hear the word of God for two weeks in his life and be willing to join Christianity without asking anything about Christian faith? It seems the preachers expected Christianity to cause rapid change to the priest. Moreover, when the priest asked the preachers to remain there for a longer period of time, he needed to have a dialogue with the preachers.

From the case study above, we can conclude that the state which the priest was left with, could make him to be half knowledgeable person about Christianity and thus unable to decide for the new faith (Christianity). Eventually the African priest will remain with his old faith (African religion) which is so demanding from his respective clan members. We can also ask, "How was it possible for the preachers to assume that such a leader of African religion to be easily converted into Christianity in two weeks' time even without having dialogue with him?"

Such style of converting people can be compared with the African wise saying, "you cannot start feeding a cow with healthy food in the morning and expect it to gain enough weight to be sold in the afternoon at the market place." In this way if you like your cow to gain more weight so that it can be sold at a reasonable price, start feeding it at least one month before taking it for sale. For this purpose, when we talk about dialogue and mission, we aim at preaching the Gospel to the non-Christian members in form of dialogue so that they can understand better and eventually if they accept Christianity they become strong in their faith.

\subsection{What can Christianity Learn from African Religion?}

Christianity has many things to learn from African religion. However, all things can be learnt when Christian church in Africa changes her mind set towards African religion. First of all, Christians must know that after being converted to Christianity, their fellow brother and sisters who are non-Christians are still part of their family members. Therefore, the role of Christianity is not to separate members but unite them since all were created by God in his image and that the salvation through Jesus Christ is for all mankind. After knowing this, the Christians can be able to see the potentialities in the African religion.

Christianity can learn from African religion about family relationship which exists in all areas of life. This relationship does not only exist in this world but even in the life to come. Due to this sense of relationship, a community member whenever behaves contrary to the community norms, affects the whole community in this world and the other world. In this case eschatological anticipation is community based rather than individual. Therefore, Christian church can learn from African religion practice and enrich the church understanding of family. For the time being, the church understanding of family or communion is rather abstract than concrete like

\footnotetext{
${ }^{1}$ Interview with Martin Chaula, Iringa Municipal Council, September 20, 2019. Mr Chaula is one of the preachers and prominent sponsors of the Crusade. When I asked him to give donation to the education programme in Makete District, where he also originates, he answered me, "I am donating to spiritual programmes like 'New Life in Christ' and not secular projects like education..."
} 
the ones in African religion. Many Christians view communion in a vertical rather than in both dimensions; vertical and horizontal dimension as African religion believers view. In African world view, family or communion is seen as first on human dimension (family relationship) and secondly is divine relationship (forebears and God).

Christianity can also learn from African religion the issue of instructing children and young people. The teaching includes social norms as well as religious ethics. Whereas, in the church instruction is mostly confined to Christian doctrine. Therefore, the Christian teaching is more orthodoxy than orthopraxis. As a matter of fact, in most of Christian communities immoralities are severe than in those of African religion believers.

Christianity can learn from African religion concerning the issue of offering. In Christianity the emphasis on offering is legalistic while in African religion offering is based on hospitality. Due to this background, the African religion use less effort to teach her followers the importance of offering since it is rooted in their culture. The experience shows that whenever offering in the church is on legalistic basis, the amount tends to be low. In Tanzania for example, the missionaries who worked in the Northern part (Leipzig Mission Society from Germany) adopted the African way of offering based on hospitality, as a result the church offering to this day is not only voluntary but church members give large amount and the church is very rich. This is unlike the Southern part of Tanzania where the other type of missionaries (Berlin Mission Society from Germany) emphasized offering on legalistic basis. In this case, Christianity has little to offer African religion followers in regards to hospitality. Instead, Christianity can learn a lot from African practice of hospitality which has a socioreligious dimension.

African religion has wider perspective regarding fire. In African community, fire plays vital role in social as well as religious aspect. Moreover, in religious aspect, fire plays an eschatological hope, whereby, as it plays a role of hospitality, livelihood, unity in this world, it plays also a positive role in the world to come where it will play a unifying force among family members and clans. Due to this African positive socio-religious aspect, Christianity can learn this function of fire instead of the present over-emphasis of negative aspect of fire.

Christianity should learn to view fire also in other dimensions which are available also in the Bible instead of taking one aspect of fire which is in the form of image (in the Bible) and take it as reality. When Christianity limits in negative aspect of fire, it reduces other chances of expressing fire in a positive way as can be experienced in African religion and Biblical texts which corresponds to the African world view. If fire is viewed as instrument of God's punishment, it reduces the position of God to be like human being who only revenges human beings and thus showing no other positive side of God which is love.

\subsection{What can African Religion Learn from Christianity?}

The African religion followers can also learn from Christianity as there was possibility for Christianity to learn from African religion. The African religion followers can learn something crucial concerning the attribute of Supreme God. In Christianity God does not live in remove as African religion followers understand. He lives in the midst of his people. For that reason, when believers pray do not need a mediator because He can be reached directly through prayers. Therefore, the African religion followers can learn in Christianity how to approach God directly instead of reaching Him indirectly through forebears. In connecting to this human-God relationships, the African religion followers can learn that Jesus Christ who is a savior of all mankind He is God and therefore not in the same level with forebears. Moreover, Jesus was given as a sacrifice for the whole world. Therefore, people are not supposed to perform sacrifices any more. In this case, a ransom given for violation against violation of sacred sites Kisiki-munu (human being given as ransom in order to save the family) done in African religion has no use, instead it is only enslaving an innocent child.

The African religion followers can also learn in Christianity that family hood exceeds clan or tribal level. Unlike in African religion, in Christianity family hood reaches national as well as international level. Therefore, when we talk of Gospel as good News, we are talking of ministry that crosses the family, clan, tribe as well as national frontiers and spreads globally. For that purpose, when in Christianity we talk about salvation it is worldwide, unlike in African religion where salvation is viewed in the spectrum of family, clan and tribe.

\subsection{Things to be Avoided by Christian and African Religion Followers}

After pointing out various aspects from both religions that can be mutually learnt (as discussed in sections above), it is important to see also some elements in both religions that can be avoided by followers of each religion. If we start with Christianity, we can point out the following elements to be avoided as to maintain good relationship and eventually do mission among African religion followers: The Christians should avoid calling non-Christians as barbaric people, idol worshippers, fetish worshippers or pagans, the word which is translated in Kinga language as outcast people; the Christians should not continue thinking that God's revelation was limited only to Christians, and therefore, God loves only Christians and hates non-Christian members; the Christians should stop regarding African religion practice of puberty initiation as Satanic practice; Christians should also avoid regarding forebears as Satan. 
On the other side, African religion followers should avoid the following: to think that if at all accept Christianity they can practice both religions concurrently, by thinking that Christianity must play additive role. Therefore, if they decide to be Christians they must serve only one religion at a time; the African religion followers should consider the practice of forebear veneration not to exceed and to be seen like adoration instead of being veneration. The African religion followers seem to be too much committed to activities related to forebears as if they are living beings.

\section{Conclusion}

This work, Interfaith dialogue in an African context shows that African religion is a living religion. Therefore, if any one intends to do a research, should not go to the museum, but participate in community's daily activities which are in a form of socio-religious aspect (inseparable between secular and religious aspect). When presenting African religious aspects, the intention was not to show only attractive aspects; instead it was to show both parts of the coin: elements that are not worth and those which are worthy to be preserved.

In the course of surveying African religion, It has been also noted that through passing various stages of the history namely: colonialism and missionary enterprise, African religion due to lacking scripture, it suffered injustices that can be seen through the way it has been named: paganism; heathenism; fetishism; animism; idolatry, primitive and native, ancestor worship, polytheism, witchcraft and sorcery, syncretism and totemic.

Due to this negative picture given during colonialism and missionary era, it has caused a risk of interacting with African religion followers. In this case, a Christian is not expected to participate in African religious activities such as communal meals, funeral ceremonies, wedding functions, any kind of initiation rites etc. Moreover, it is a risk for a Christian to do research on African religion and once is seen, he/she will be admired as why he/she is doing research on such demonic practices.

To the question as whether is it possible or necessary for Christian Church to dialogue with African religion, some people contend that it is impossible for such dialogue to take place. They argue that in African religion there are no structure and no personality to deal with. However, on the other side we cannot deny the fact that African religion is still influencing people's thinking. Many highly educated people, Christians and Muslims are affected by it though sometimes unconsciously. Moreover, during the time of crisis, Africans who are converted Moslems or Christians go back to African religion to seek for solution of their problems; African religion is the background of all converted Muslims and Christians, therefore it can be the area of research for the two foreign religions for the sake of doing enculturation. This being the case, the need for the church to dialogue with African religion becomes significant.

The survey also shows the other benefit of dialogue with African religion is to learn from this religion, this can help Africans: whether Muslims or Christians to preserve their cultural identity. For the time being there is a demand of cultural tourism in the world whereby, classic tourism is no longer popular, in this case the Africans who value their culture can be part of beneficiary of cultural tourism industry. However, if they are against cultural preservation, they can either participate in destroying or they can let foreigner benefit from their cultural tourist destinations.

\subsection{A Way Forward}

As a way forward, I can remind Africans that, let us not make similar mistakes as colonialists and missionaries did in the past. We should not participate in persecuting African religion. In African theological seminaries, African religion either was established by Western scholars for the sake of doing anthropological researches. Therefore, for the time being the subject is still taught with similar goal. In most of seminaries, the subject is taught in one semester, there is no curriculum development for this subject, instead, the Africans continue teaching similar topics and emphasis established by Western scholars who initiated the subject.

The African religion subject is taught only in undergraduate programs therefore, there are no efforts to start post graduate programs for Master and $\mathrm{PhD}$ in African Religion and Philosophy. Worse enough, in many seminaries, African religion is still taught by Western scholars. To comment this does not mean that Western scholars cannot teach African studies, there are many scholars who have written their scholarly work in an African scholarship. However, when teaching this subject in African context, African scholars should be in front and not in the background.

The Church in Africa which is now more than one hundred years old (excluding Ethiopia and Egypt) should have now produced a lot of scholars who should have done enculturation of the Gospel. Moreover, the contributors in the African Religion Journals, authors of books and article in Encyclopedias of African Religion (in many parts of the world), were supposed to be the majority Africans. However, the reality is not. Many contributors of this scholarly work about African Religion are Western scholars. I therefore, encourage Church in Africa and her scholars to put more emphasis on research on African religion and emphasis on dialogue with African religion so that we can build a good foundation of our context first, then we can be able to pursue other theological disciplines like New Testament, Old Testament, Systematic and Pastoral Care and Counseling. 
If we neglect research and dialogue with African religion, issues that are in hot discussion in the Western World such as homosexuality can be too remote for African church to understand and be active participants in discussion. It is my conviction that this work cannot only serve African Church, but also church in Europe, America and Asia and where either there are African Europeans/Americans or African immigrants who are increasing year after year.

\section{Reference}

- Ambe, J., B. (1992). Meaningful Cerebration of the Sacrament of Reconciliation in Africa, Eldoret

- Battle, Michael. (2009). Ubuntu: I in You and You in Me, New York- USA.

- Battle, Michael. (1997). Reconciliation. The Ubuntu Theology of Desmund Tutu, Ohio.

- Kilaini, Method, The Church in Africa. (online) Available: http://www.apostleshipofprayer.net/docs/TheChurch-in-Africa-and-Tz-EN.pdf

- Boos, Eric. (1998). Evangelization through Dialogue and Enculturation. Journal of African Ecclesial Review (AFER) Vol. 40. No. 2, 66-84.

- Bujo, Benezet. (1986). Afrikanische Theologie in ihrem gesellschaftlichen Kontext. Duesseldorf.

Chidi, Denis., Isizoh. (2011) Dialogue with African Traditional Religion in Sub-Saharan Africa: The Changing Attitude of the Catholic Church. Online. Available: (http://www.africaworld.net/afrel/religion-inafrica.htm).

-Dictionary of Etymology. (1988). Barnhart, K. Robert (Ed.). The H.N. Wilson Company- USA.

- Koenig,John. (2005). Hospitality. In Lindsay, Jones (ed.) Encyclopedia of Religion Vol I, USA.

- Gittins, Antony J. (1998, pp. 87-89). Conversion in: Mueller, Karl, Sundermeier, Theo, Bevans, B. Stephen, Bliese, H. Richard (eds.) Dictionary of Mission, Ohio.

- Ilomo, Falres. (2013). A Relevant Christian Eschatology for African Context Today, Dar es Salaam University Press- Tanzania.

- Ilomo, Falres. (2013). African Religion: A Basis for Interfaith Dialogue Today, Dar es Salaam University Press- Tanzania.

- Ilomo, Falres. (2011). Christianity: A Secondary Religious Experience among People of Livingstone Mountains, Vuga Press-Soni- Tanzania.

- Kenneth, Cracknell. (1986). Towards a New Relationship: Christians and people of other Faith, London.

- Koizumi, Mari. (November 1995). Meaning of Conversion: Cosmology, Politics and Moral Discourse among the Kinga of South Western Tanzania. [Unpublished doctoral dissertation]. University of Yale University).

Panikkar, Raimon. (1999). Intra-Religious Dialogue, Revised Edition, Paulist Press, New York-USA. www.africaworld.net/afrel/metuh.htm

-Religious Peace Conference in Dar es Salaam-Tanzania (July 25, 2016): cct-tz.org/

-Sundermeier, Theo. (1998). The Individual and Community in African Traditional Religions, LIT Verlag Hamburg.

-Tamko la Viongozi wa Dini 17 September 2015 (Declaration of Religious Leaders concerning Freedom, Justice and Peace: cct-tz.org/tamko-la-viongozi-wa-dini-uhuru-haki-na-amani/

- Kamera, W.D. (1986). Loo Ammohhuuma: An Iraqw Reconciliation Rite in: Anthropos 81.

- Workshop of Religious Leaders on Peaceful Co-existence in Tanzania (17/9/2015): cct-tz.org 